WAK 131997
$8 t \pi, 37$

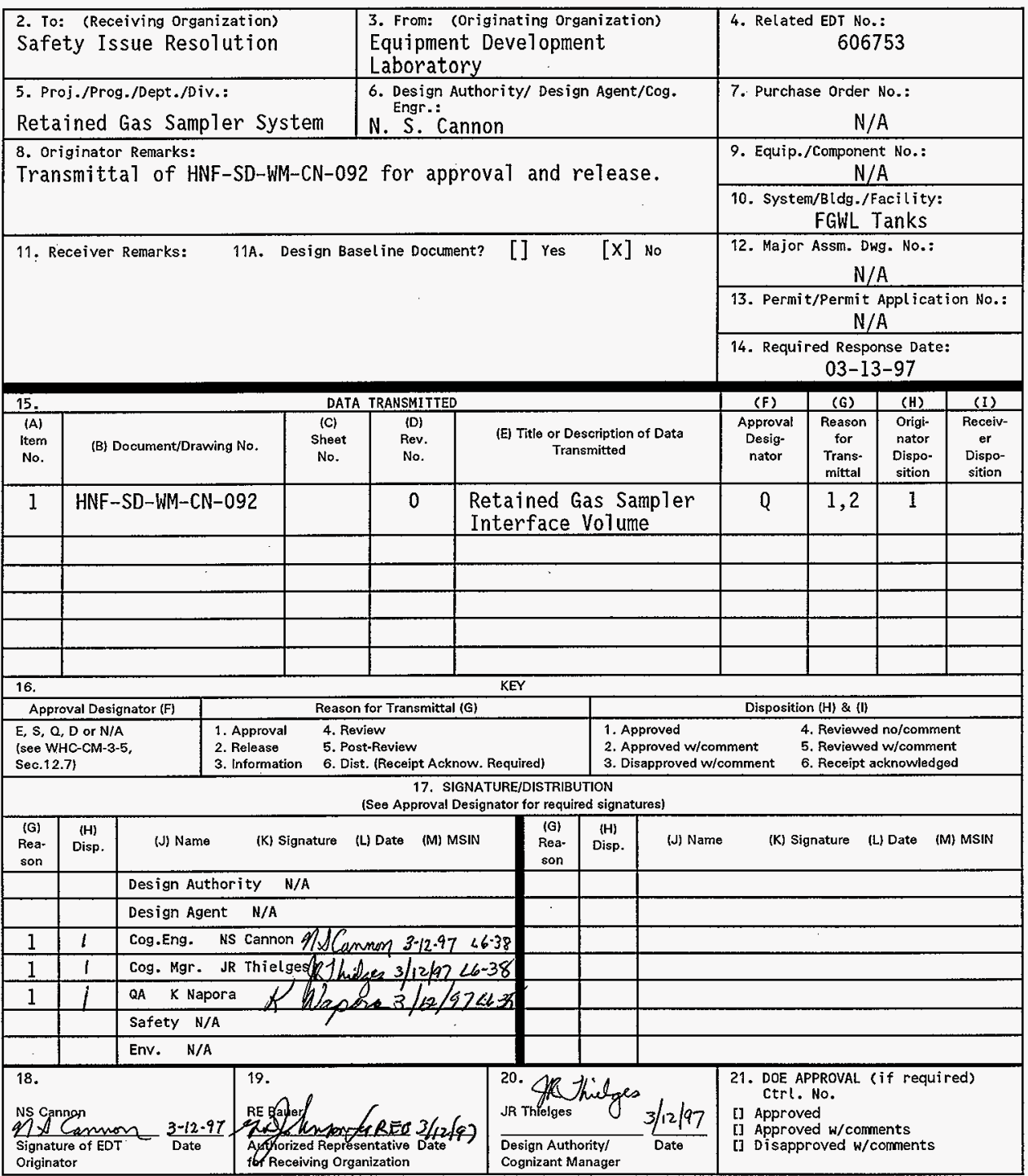

BD-7400-172-2(05/96) GEF097 


\title{
Retained Gas Sampler Interface Volume
}

\author{
N. S. Cannon
}

SGN Eurisys Services Corporation, Richland, WA 99352

U.S. Department of Energy Contract DE-AC06-96RL13200

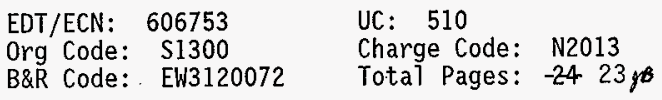

Key Words: Retained Gas Samp]er, RGS Contamination Volume, Interface Volume, HeTium Backfi11, RGS Air Contamination, RGS Purge Gas Contamination

Abstract: The maximum Retained Gas Sampler (RGS) interface volume was determined; this volume can trap contamination gases during the sampling process. A new technique (helium backfill) for eliminating contamination gases from the RGS sampler interface volume is described, and verification testing reported. Also demonstrated was that RGS data obtained prior to the introduction of the new helium backfill technique can be compensated for air contamination using the measured oxygen concentration and normal air composition.

TRADEMARK DISCLAIMER. Reference herein to any specific commercial product, process, or service by trade name, trademark, manufacturer, or otherwise, does not necessarily constitute or imply its endorsement, recommendation, or favoring by the United States Government or any agency thereof or its contractors or subcontractors.

Printed in the United States of America. To obtain copies of this document, contact: Document Control Services, P.0. Box 950, Mailstop H6-08, Richland WA 99352, Phone (509) 372-2420;

Fax (509) 376-4989.
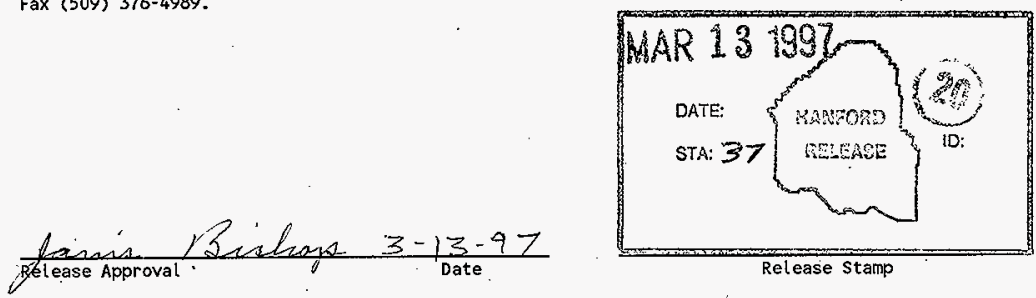

\section{Approved for Public Release}


Page 1

\title{
RETAINED GAS SAMPLER INTERFACE VOLUME
}

\author{
N. S. Cannon
}

March 1997 


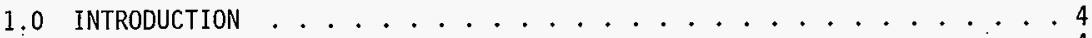



1.2 Retained Gas Sampler Interface Volume Description .......4

2.0 INTERFACE VOLUME DETERMINED EXPERIMENTALLY ........... 4

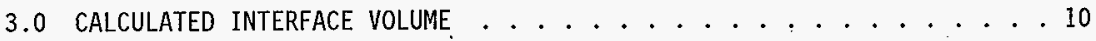

4.0 INTERFACE VOLUME HELIUM BACKFILL . . . . . . . . . . 11

4.1 Helium Backfil Technique . . . . . . . . . . . . . . 11

4.2 Helium Backfill Laboratory Verification Testing . . . . . . . . . 11

4.3 Helium Backfill RGS Results .............. 12

4.4 Contamination Gas Volume Comparisons ........... 12

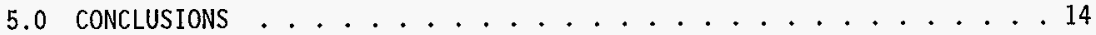

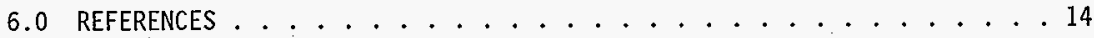

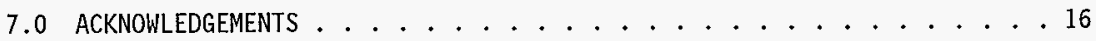

\section{Appendixes}

A Interface Volume Raw Data/Analysis . . . . . . . . . . . A-1

B Interface Volume Gas Transfer During Sampi ing .......... B-1

\section{Figures}

1 Simplified Sketch of the RGS Geometries Producing the Interface Volume . 5

2 Sketch of the RGS Sampler/Dri11 Bit Configuration Prior to Sampling. . . 6

3 Interface volume Measurement Test Setup. Two configurations were used to determine the interface volume, as shown. . . . . . . . 7

4 The Portion of Sampler Piston Protruding Beyond the Sampler Interface is Illustrated. The volume $V_{0}=\pi\left(0.99^{2}+0.93^{2}\right) / 2 *\left(0.8 \mathrm{in}^{3}\right)=$ $9.48 \mathrm{~cm}^{3}$. The rounded edges at the piston end have negligible effect

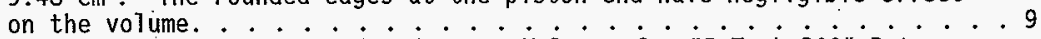

5 Comparison Plot of Contamination Gas Volumes for " 5 Tank RGS" Data, Helium Backfill Testing Data, and U-103 Helium Backfill Sampler Data. . 13

6 RGS 0xygen Concentration Related to Lag Time. ......... 15

\section{Tables}

A-1 Helium Backfill Verification Testing Raw Data: 7-3-96, Configuration 1........ . A-1

A-2 He]ium Backfil1 Verification Testing Raw Data: 7-3-96, Configuration 2 . . . . . . . . . . A-1

A-3 Helium Backfill Verification Testing Raw Data: 7-15-96, Configuration 1................. . . .

A-4 Helium Backfi11 Verification Testing Raw Data: 7-15-96, Configuration $2 \ldots \ldots \ldots . . \ldots$. . . . . . . . 


\section{CONTENTS (Cont.)}

Tables (cont.)

B-1 Laboratory Simulation Tests - Helium Backfilled Samplers. . . . . . B-1

B-2 RGS Trapped Air Volume Determination. ............ . B-2

B-3 Statistics for RGS "Contamination" Volumes at STP . . . ....... B-3

B-4 Effectiveness of Helium Backfill Technique. . . . . . . . . . B-4 


\title{
RETAINED GAS SAMPLER INTERFACE VOLUME
}

\author{
N. S. Cannon
}

$(3-11-97)$

\subsection{INTRODUCTION}

When a Retained Gas Sampler (RGS) is lowered down the drill string, there is an external "interface" volume in which air or purge gas can be trapped. During the actual segment sampling, some or all of this external gas may inadvertently be included as part of the. RGS sample, adding to the sample gas composition and volume errors.

\subsection{Purpose}

The purpose of the work reported here was to determine the maximum value of the interface volume using an experimental method, and additionaliy by direct calculation. Also presented in this report is a new technique to eliminate this RGS contamination from interface volume gases by using a sampler helium backfill method. Validation testing results for this technique are included. In addition, it is shown that previous RGS tests (Shekarriz, 1996) performed before the helium backfill technique was developed can be compensated for air contamination using oxygen concentration results and normal air composition.

\subsection{Retained Gas Sampler Interface Volume Description}

A sketch of the valve end of the RGS (a simplification of details provided in drawing H-2-821608) is given in Figure 1. The RGS piston starts in an extended position $(0.8$ inches, $2 \mathrm{~cm}$ ) beyond the sampler "interface" insert before the actual. sample is taken. This extension lines up the end of the piston with the end of the drill bit, as illustrated in Figure 2. Having the piston flush with the end of the drill bit minimizes the amount of waste dragged along with the bit as the drill string is lowered into the tank. This positioning assures a more representative sample at individual tank locations.

As a sampler is lowered into the tank waste, the waste will trap air/purge gas in any volumes that exist between the sampler interface and the piston o-rings (see Figure 1). The total volume available to trap.gas in this way is defined as the interface volume $\left(V_{I}\right)$.

\subsection{INTERFACE VOLUME DETERMINED EXPERIMENTALLY}

A test was devised to measure this interface volume using pressurization of the sampler interface with helium or argon (starting with a known charge volume, pressure and temperature) and the ideal gas 1aw. Two test configurations were used and are sketched in Figure 3.

In test Configuration 1, a polished surface "blank-off" disk was pressed against the attachment chamber's sealing o-ring, creating a basic system 


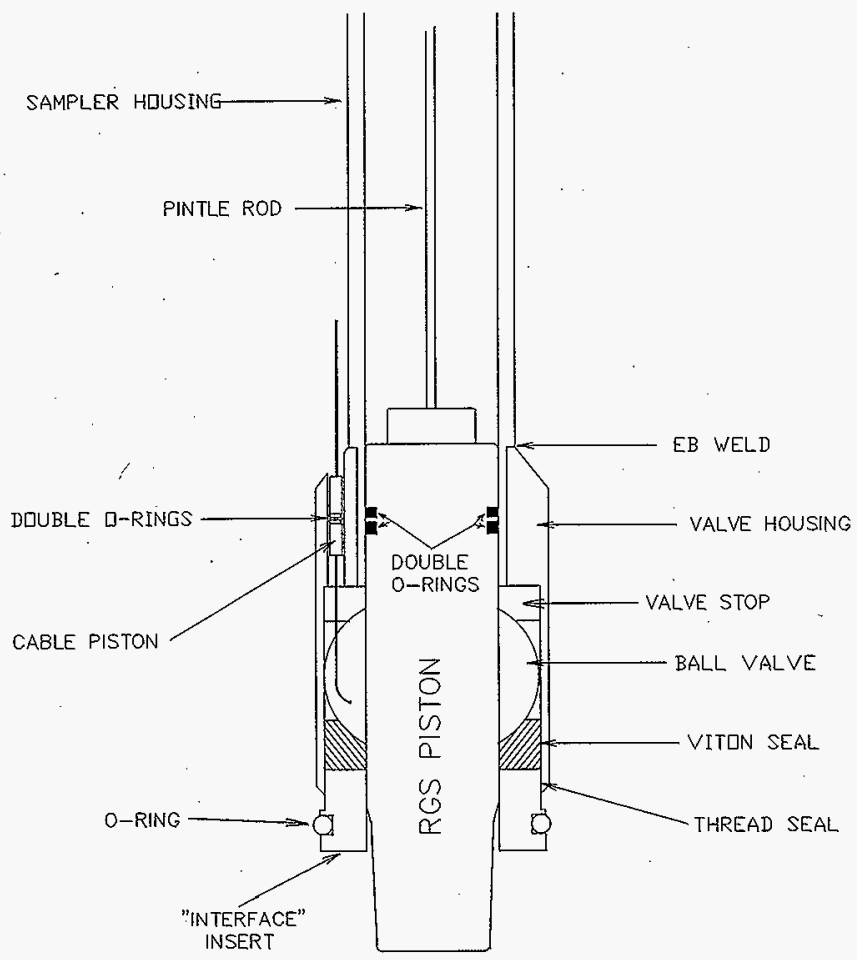

Figure 1. Simplified Sketch of the RGS Geometries Producing the Interface Volume. 


\section{RGS SAMPLER/DRILL BIT·CONFIGURATION}

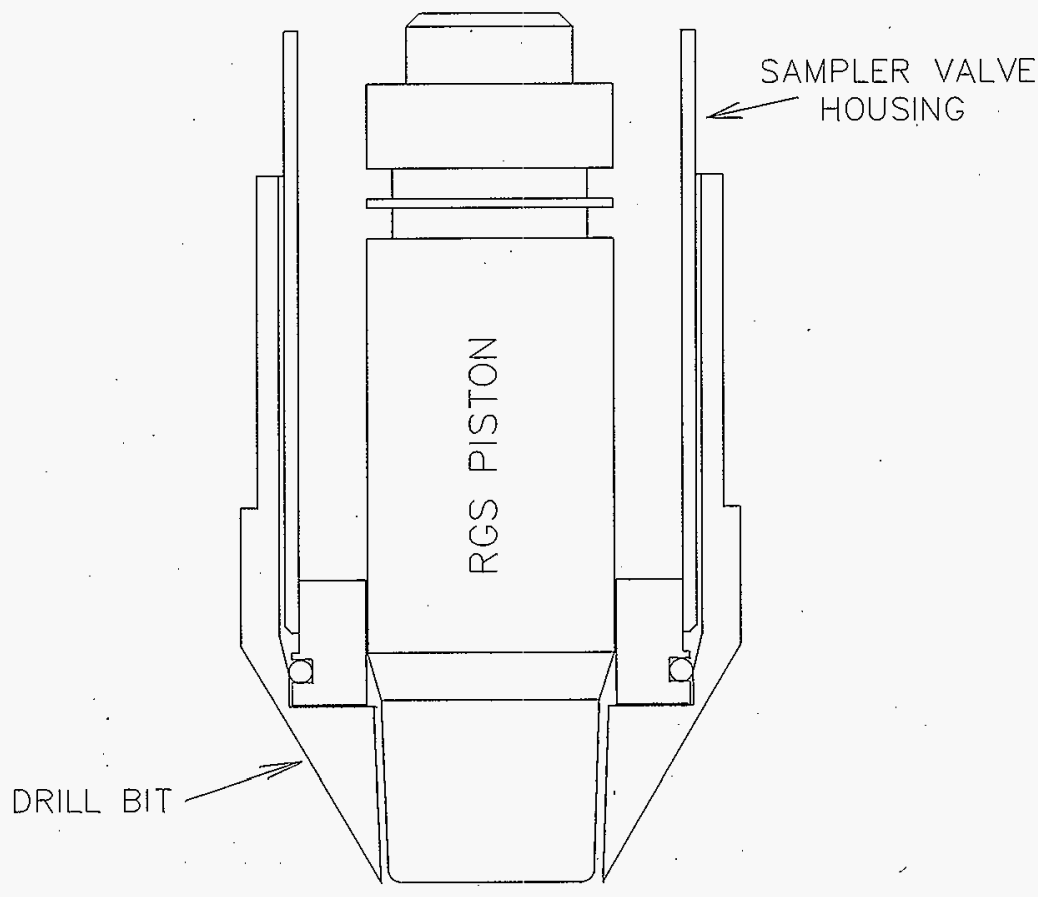

Figure 2. Sketch of the RGS Sampler/Drill Bit Configuration Prior to Sampling. 




음



$\stackrel{9}{+}$

?

$\frac{\Phi}{3}$

气

范

$\stackrel{9}{1}$

递

$\stackrel{4}{4}$

产

$\vdots$

跣

$\sum$

氖

응

啘

乐

Е.

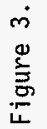


volume of $V_{b}$. The volume defined as $V_{b}$ includes the attachment chamber volume, line volumes and the main vacuum chamber volume that are shown in Figure 3. The main chamber volume also includes two pressure transducers, PXD1 and PXD2, which are not shown in the Figure.

The value of $V_{b}$ was determined by charging the system, including the reference canister (of known volume $V_{c}$ ) with gas through valve $A$ (Valve $B$ closed and Valve $C$ open) to a starting pressure $\left(P_{1}\right)$ at ambient temperature $\left(T_{a}\right)$. Then, with Valves $A$ and $C$ closed, the remaining volume was evacuated through Valve $B$, leaving only $V_{c}$ charged at $P_{1}$. After evacuation;, Valve $B$ was closed and $V$ alve $C$ was opened allowing $V_{c}$ gas to produce a new pressure $\left(P_{2}\right)$ in $V_{b}$, eventually at the same temperature $T_{a}$. The volume $V_{b}$ was then calculated from the ideal gas law as

$$
V_{b}=\left(\frac{P_{1}-P_{2}}{P_{2}}\right) V_{C}
$$

The reference canister volume had previously been measured by weighing it dry, and then filling it with water (essentially bubble free) and reweighing it. Using the water density, the canister volume was determined as $V_{c}=40.09 \mathrm{~mL}$.

In test Configuration 2, Sampler PR2 was mounted to the attachment chamber as also shown in Figure 3 . The sampler piston was extended beyond the sampler o-ring insert assembly (sealing surface) 0.8 inches. $(2 \mathrm{~cm}$ ), as is required when the sampler is placed in the drill string for tank sampling. The volume of the portion of the piston extending beyond the sampler sealing surface is defined as $V_{0}$ and easily calculated from the simple geometry sketched in Figure 4 as $9.48 \mathrm{~mL}$. The new system volume $\left(V_{n}\right)$ was then determined by charging the reference volume with gas and discharging it into the system volume as previousty described, where

$$
V_{n}=\left(\frac{P_{1}-P_{2}}{P_{2}}\right) V_{c}
$$

The sampler interface volume $\left(V_{I}\right)$ can then be determined from

$$
V_{I}=\left[V_{n}+V_{p}\right]-V_{b}
$$

Data was obtained on July 3, 1996 using helium gas, and another set of data was taken July 15, 1996 using argon gas; raw data and analysis of this data are given in Appendix A. The helium gas tests resulted in a value of $6.08 \mathrm{~mL}$ for the interface volume while the argon test data produced a value of $6.10 \mathrm{~mL}$. 


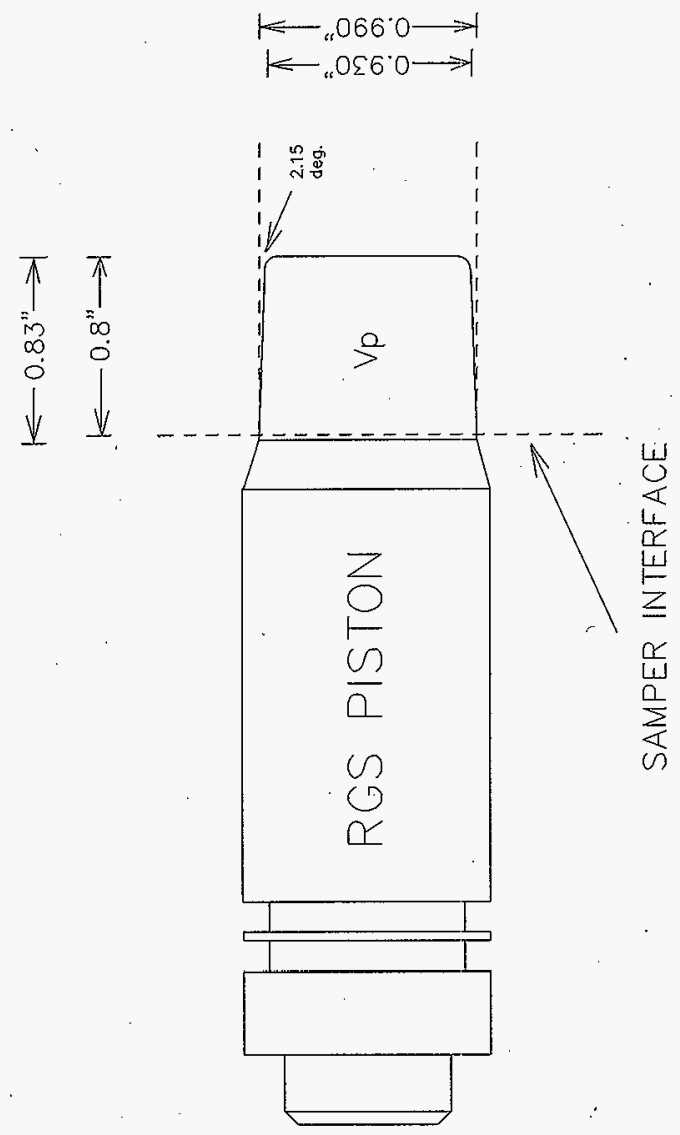

$\Phi$.

일 든

믈

它 $\infty$

+ᄂ

¿*

웡

도

ะ

50

$\overline{0}+\underline{U}$

ही

तั 5

$4 \dot{0}$

4 开至

든 11

눔 $=\therefore$

응

힝

동요

$\dot{8}$
0
$\frac{5}{3}$
$\frac{1}{4}$ 
These are remarkably consistent values for $V_{I}$ considering that two different transducers (with different pressure ranges) were used for the volume determination. Also the test system volume was changed by about $0.9 \mathrm{~mL}$ between the two testing days while the system was used for other purposes.

\subsection{CALCULATED INTERFACE VOLUME}

Early in the RGS program, the interface volume had been estimated as about $1.1 \mathrm{~mL}$, based on determining the "gap volume" between the sampler piston and the sampler tube. As a result of the experimentally determined interface volume of $6.1 \mathrm{~mL}$, a re-evaluation of the valve assembly construction was performed.

Re-examining the schematic of the sampler valve assembly shown in Figure 1 , it can be noted that there is a substantial annulus volume within the Valve Housing component that is occupied by a total of three sampler parts:

Valve Stop - Stationary component behind the valve. Viton Seal - Stationary component in front of the valve. Rotary VaTve - Rotates 90 degrees during valve closure.

Using engineering drawing nominal dimensions, the empty volume of this annulus was calculated to be $29.7 \mathrm{~mL}$. Note that this volume may vary somewhat from sampler-to-sampler due to the exact final position of the threaded Insert. However, inspection of several completed samplers indicated that this variation would effect the volume by less than $\pm 0.5 \mathrm{~mL}$.

The next step was to determine the volume of the three individual components that occupy this annulus. This was done using weight and density data for each component. The results were as follows:

$$
\begin{aligned}
\text { Valve Stop } & =9.8 \mathrm{~mL} \\
\text { Viton Seal } & =5.7 \mathrm{~mL} \\
\text { Rotary Ball Valve } & =9.3 \mathrm{~mL} \\
\text { Total } & =24.8 \mathrm{~mL}
\end{aligned}
$$

Therefore, the void volume for this section of the RGS valve assembly, which may be expected to be filled with air or other external gases when the sampler is inserted into the waste, is calculated to be:

$$
29.7 \mathrm{~mL}-24.8 \mathrm{~mL}=4.9 \mathrm{~mL}
$$

This volume, coupled with the gap volume previously evaluated, results in a total void volume of approximately $6.0 \mathrm{~mL}$, in close agreement with the volume determined using the ideal gas 1 aw.

Another test series should be mentioned which was performed by $M$. White to measure the interface volume using a water fill method (White, 1997). A 
syringe was used to force water into void spaces and displace air, with weight measurements resulting in an interface volume determination of $5.72 \mathrm{~mL}$. This value is slightiy smaller than those previously determined, which is not surprising considering that water's surface tension would reduce its ability to penetrate through small openings. However, it is clear that these three different methods for determining the interface volume are in relatively good agreement with a value of $6 \mathrm{~mL}$.

\subsection{INTERFACE VOLUME HELIUM BACKFILL}

In most cases, oxygen was found in the RGS gas samples from the first five tanks tested (Shekarriz, 1996). This oxygen has been attributed to air trapped in the interface volume of the sampler as it is lowered into the tank. If a minimal oxygen interaction with the waste is assumed, then the original quantity of air introduced into the sample can be calculated based on normal air composition. This calculation is performed for the RGS data in Appendix B (see Table B-2); the resulting trapped air volumes generally fall within 1.3 to $4 \mathrm{~mL}$ (at STP). All of the air volumes determined were less than $4 \mathrm{~mL}$. It appears that not all of the sampler interface gas was released into the sampler during the sampling process, or that some oxygen reacted with the waste, or that some argon purge gas may have been included in the interface gases. This subject will be discussed later in greater detail in Section 4.4.

\subsection{Helium Backfill Technique}

In order to minimize the problem of RGS contamination from extraneous gases trapped in the interface volume, a heljum backfill technique has been developed. After an RGS sampler has been fabricated, it is placed in a glove box that is evacuated and then backfilled with helium. The RGS piston is then moved forward to its final position through vacuum grease that seals the helium into the interface volume. As an extra precaution, the sampler is enclosed in a hermetic stainless steel cylinder for shipping, also backfilled with helium. This provides a double helium barrier that ensures that the interface volume helium will not leak out (tested to over 1000 hours of storage time).

Helium was chosen for the backfill gas because it is inert, inexpensive, and not found in the Hanford waste tanks. When helium is detected in the RGS sampler gases, it is discarded from the composition analysis as a known and quantified contaminant.

\subsection{Helium Backfill Laboratory Verification Testing}

The helium backfill concept was tested by "aging" backfilled samplers and then recovering the interface volume gas to analyze for composition and quantity. This was done by installing the sampler. in the Configuration 2 position (see Figure 3). An extra o-ring seal (not shown in Figure 3) was installed over the piston to seal against the interface ring which prevented the interface 
volume gases from being lost when the attachment chamber, main vacuum chamber and reference canister were evacuated.

Valve $B$ was then closed to isolate the vacuum chamber(s) from the pump, and the RGS piston was pulled back so that the RGS ball valve could be closed (simulating taking a sample). After a few minutes, the ball valve was again opened, allowing the interface gases released (by taking the "sample") to flow into the rest of the system. The piston was again pushed forward to its original position (re-establishing the known system volume). The pressure and temperature were measured to determine the quantity of released interface gas; then Valve $C$ was closed and the reference canister removed so that mass spectrometer composition analysis could be performed. The raw data from these tests is given in Appendix B, Table B-1.

\subsection{Helium Backfilled RGS Results}

Development of the helium backfill technique for the RGS was completed after testing in the first five tanks was finished. However, helium backfilled samplers were introduced when sampling was restarted in the next set of RGS tanks, beginning in tank U-103. Although it is premature to report the complete results obtained from new RGS tanks, an evaluation of the effectiveness of the helium backfill samplers is made here for the first four RGS segments obtained in U-103. The raw data for the quantities of helium and oxygen identified in those samples is given in Appendix B, Table B-4.

The backfill technique was very successful in replacing the interface trapped air with helium; helium quantities ranged from 2.2 to $4 \mathrm{~mL}$ in the four samples, 0xygen levels were significantly reduced, and calculated air contamination was generally less than $0.5 \mathrm{~mL}$; in fact, the air volumes calculated were consistent with test system in-leakage over the duration of the gas extraction process.

\subsection{Contamination Gas Volume Comparisons}

The successful effort to validate the helium backfill technique for RGS samplers also provides the opportunity to compare the "contamination" gas volumes observed from several different types of RGS tests. This comparison is useful in making a qualitative evaluation of the potential oxygen reaction with waste within the RGS sampler. If it can be shown that the oxygen/waste reaction is minimal, then the data from the first five RGS tanks can be more easily adjusted to eliminate contamination effects from the sampler interface volume. (Interface volume contamination is not expected to be a problem for future RGS samples because of the helium backfili technique.)

In Figure 5, a comparison is made of the contamination volumes determined from the first five RGS tank data, the helium backfill validation data, and the new helium backfilled sampler results from $U-103$. As used here, the 
苞

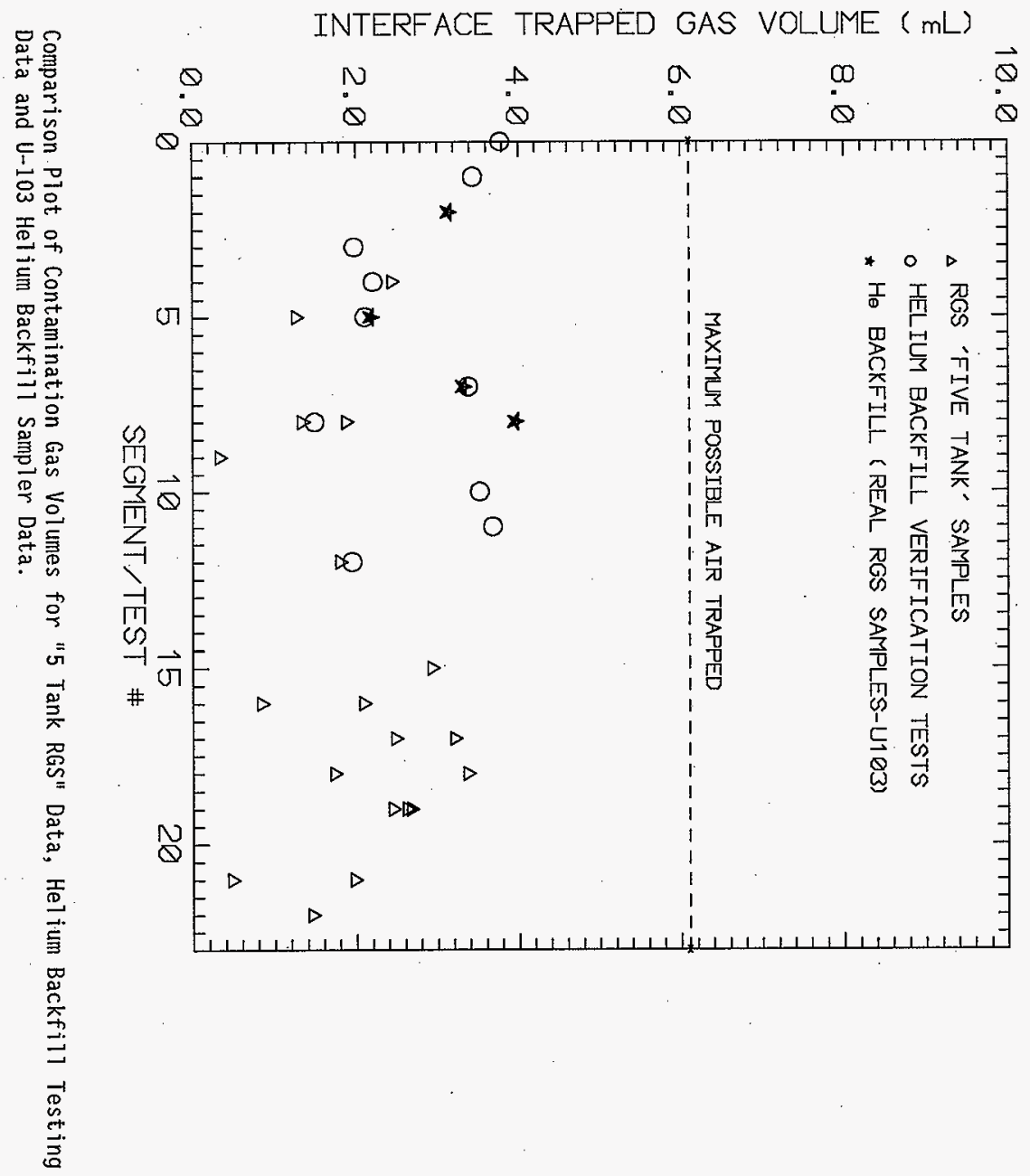


"contamination" gas volume refers the quantity of gas released from the RGS interface volume into the sampler when the sample is obtained.

There are several points that can be made from Figure 5 . It is clear that not all of the available interface gas enters the sampler when the valve is closed. Also, it appears that roughly the same range and scatter is observed for all three types of data (see Appendix B, Table B-3 for a statistical evaluation). Since there is no oxygen/waste interaction possible during the helium backfill testing, and this data for the most part matches the five tank data, it is concluded that oxygen/waste reaction within the RGS sampler over the lag time between taking the sample and testing it is minimal. This conclusion is further supported by examining a plot made by $L$. A. Mahoney (Shekarriz, 1996) comparing oxygen content with the lag time. This plot has been updated and reproduced here for the reader's convenience as Figure 6 . The data presented does not support any significant decrease in RGS oxygen concentration versus lag time.

\subsection{CONCLUSIONS}

The RGS sampler interface "trapping volume" determined experimentally for Sampler PR2 was. about $6.1 \mathrm{~mL}$; this value is in good agreement with the calculated value of $6.0 \mathrm{~mL}$ based on drawing dimensions. Sampler-to-sampler volume variation is expected to be less than $\pm 0.5 \mathrm{~mL}$.

Although there is a $6 \mathrm{~mL}$ sampler interface volume to trap air (or purge gas) as the sampler is lowered through the drill string into the tank waste, not all of this contamination gas is drawn in with the waste sample; it is concluded that this "draw-in" is almost always less than $4 \mathrm{~mL}$.

The "five tank" RGS data given in the preliminary report (Shekarriz, 1996) can be corrected for interface air contamination using the measured oxygen concentrations and normal air composition.

Testing of the helium backfill technique in the laboratory, and preliminary results from tank U-103 (the first four helium backfilled samplers used in the field) indicate that this technique should minimize interface gas contamination for future RGS testing.

\subsection{REFERENCES}

A. Skekarriz, et. a1., "Preliminary Retained Gas Sampler Measurement Results for Hanford Waste Tanks 241-AW-101, 241-A-101, 241-AN-105, 241-AN-104, and 241-AN-103," PNNL-11450, December 1996.

M. White, Letter Report, "Retained Gas Sampler Lab Tests," PNNL TWSMIT:090596, February 6, 1997. 




Figure 6. RGS 0xygen Concentration Related to Lag Time. 


\subsection{ACKNOWLEDGEMENTS}

The author wishes to express his appreciation to R. C. Knight who performed the calculation of the interface volume from system drawings. L. A. Mahoney provided Figure 6 , which is also greatiy appreciated. 
APPENDIX A

Interface Volume Raw Data/Analys is

The raw data for the tests with helium described in Section 2.0 are given in Tables $A-1$ and $A-2$.

\begin{tabular}{|c|c|c|c|}
\hline \multicolumn{4}{|c|}{ TABLE A-1 } \\
\hline Date: $7-3-96$ & $\begin{array}{l}V_{c}=40.06 \mathrm{~mL} \\
\text { Gas }=H e\rceil \text { ium }\end{array}$ & $\begin{array}{c}\text { Transducer: } 100 \mathrm{~T} \\
\# 835-80-02-003\end{array}$ & $\begin{array}{c}\text { Test Temperature } \\
25^{\circ} \mathrm{C} \\
\end{array}$ \\
\hline $\begin{array}{c}\text { Test } \\
\text { Configuration }\end{array}$ & $\begin{array}{c}\text { Charge Pressure } \\
\text { P1 (KPa) }\end{array}$ & $\begin{array}{c}\text { Combined Pressure } \\
\text { P2 }(\mathrm{KPa})\end{array}$ & $\begin{array}{c}\text { Calculated Vol. } \\
V_{b}(\mathrm{~mL})\end{array}$ \\
\hline \multirow{8}{*}{$\begin{array}{c}\# 1 \\
\text { Blank Flange }\end{array}$} & 99.79 & 30.21 & 92.27 \\
\hline & 98.50 & 29.75 & 92.58 \\
\hline & 98.76 & 29.81 & 92.66 \\
\hline & 100.35 & 30.28 & 92.70 \\
\hline & 101.81 & 30.73 & 92.65 \\
\hline & 49.82 & 15.05 & 92.55 \\
\hline & 53.04 & 16.01 & 92.66 \\
\hline & 51.69 & 15.60 & 92.68 \\
\hline \multicolumn{4}{|c|}{ TABLE A-2 } \\
\hline Date: $7-3-96$ & $\begin{array}{l}V_{c}=40.06 \mathrm{~mL} \\
\text { Gas }=H e 1 \mathrm{ium}\end{array}$ & $\begin{array}{c}\text { Transducer: } 100 \mathrm{~T} \\
\# 835-80-02-003\end{array}$ & $\begin{array}{c}\text { Test Temperature } \\
25^{\circ} \mathrm{C}\end{array}$ \\
\hline $\begin{array}{c}\text { Test } \\
\text { Configuration }\end{array}$ & $\begin{array}{c}\text { Charge Pressure } \\
\text { P1 (KPa) }\end{array}$ & $\begin{array}{c}\text { Combined Pressure } \\
\text { P2 (KPa) }\end{array}$ & $\begin{array}{c}\text { Calculated Vol. } \\
V_{n}(\mathrm{~mL}) \\
\end{array}$ \\
\hline \multirow{8}{*}{$\begin{array}{c}\# 2 \\
\text { Sampler PR2 } \\
\text { (Attached) }\end{array}$} & 101.08 & 31.38 & 88.98 \\
\hline & 96.75 & $\quad 30.02$ & 89.05 \\
\hline & 102.43 & 31.72 & 89.30 \\
\hline & 51.66 & 16.03 & 89.04 \\
\hline & 51.55 & 15.97 & 89.25 \\
\hline & 55.02 & 17.05 & 89.21 \\
\hline & 99.78 & 30.89 & 89.34 \\
\hline & 103.04 & 31.89 & 89.38 \\
\hline
\end{tabular}


From Table A-1 the average value of $V_{b}=92.59 \mathrm{~mL}$, with a standard deviation of $0.13 \mathrm{~mL}$; for Table A-2 the average value of $V_{n}=89.19 \mathrm{~mL}$ with a standard deviation of $0.14 \mathrm{~mL}$.

Calculation of $V_{1}=6.08 \mathrm{~mL}$ results from using Equation (3) and the above averages (note that $V_{p}=9.48 \mathrm{~mL}$ ).

The raw data obtained from the argon tests described in Section 2.0 are given in Tables $A-3$ and $A-4$.

\begin{tabular}{||c|c|c|c||}
\hline \hline \multicolumn{3}{|c|}{ TABLE A-3 } \\
\hline \hline Date: 7-15-96 & $\begin{array}{c}V_{c}=40.06 \mathrm{~mL} \\
\text { Gas = Argon }\end{array}$ & $\begin{array}{c}\text { Trans.: 1000 T } \\
\# 679-80-02-023\end{array}$ & $\begin{array}{c}\text { Test Temperature } \\
25{ }^{\circ} \mathrm{C}\end{array}$ \\
\hline \hline \multirow{2}{*}{$\begin{array}{c}\text { Test } \\
\text { Configuration }\end{array}$} & $\begin{array}{c}\text { Charge Pressure } \\
\text { P1 }(\mathrm{KPa})\end{array}$ & $\begin{array}{c}\text { Combined Pressure } \\
\text { P2 (KPa) }\end{array}$ & $\begin{array}{c}\text { Calculated Vol. } \\
\mathbf{V}_{\mathrm{b}}(\mathrm{mL})\end{array}$ \\
\hline \hline \multirow{2}{*}{ \#1 } & 742.6 & 225.8 & 91.69 \\
\cline { 2 - 5 } Blank Flange & 755.3 & 229.7 & 91.67 \\
\cline { 2 - 5 } & 760.8 & 231.4 & 91.65 \\
\hline
\end{tabular}

TABLE A-4

\begin{tabular}{||c|c|c|c||}
\hline \hline Date: 7-15-96 & $\begin{array}{c}V_{c}=40.06 \mathrm{~mL} \\
\text { Gas }=\text { Argon }\end{array}$ & $\begin{array}{c}\text { Trans.: 1000 T } \\
\# 679-80-02-023\end{array}$ & $\begin{array}{c}\text { Test Temperature } \\
25{ }^{\circ} \mathrm{C}\end{array}$ \\
\hline \hline $\begin{array}{c}\text { Test } \\
\text { Configuration }\end{array}$ & $\begin{array}{c}\text { Charge Pressure } \\
\text { P1 (KPa) }\end{array}$ & $\begin{array}{c}\text { Combined Pressure } \\
\text { P2 (KPa) }\end{array}$ & $\begin{array}{c}\text { CaTcu1ated Vol. } \\
V_{n}(\mathrm{~mL})\end{array}$ \\
\hline \multirow{2}{*}{$\begin{array}{c}\text { C2 } \\
\text { Sampler PR2 } \\
\text { (Attached) }\end{array}$} & 769.1 & 240.0 & 88.32 \\
\cline { 2 - 4 } & 754.0 & 235.4 & 88.25 \\
\hline
\end{tabular}

From Table A-3 the average value of $V_{b}=91.67 \mathrm{~mL}$, with a standard deviation of $0.02 \mathrm{~mL}$; for Table A-4 the average value of $V_{n}=88.29 \mathrm{~mL}$ with a standard deviation of $0.03 \mathrm{~mL}$.

Again, calculation of $V_{1}=6.10 \mathrm{~mL}$ results from using Equation (3) and the above averages. 


\section{APPENDIX B \\ INTERFACE VOLUME GAS TRANSFER DURING SAMPLING}

The RGS sampler interface volume has been measured at $6.1 \mathrm{~mL}$. However, as will be shown, not all of the interface trapped gas is transferred inside the sampler during sampling.

A series of tests were performed to verify the effectiveness of the helium backfill technique in eliminating air contamination of the RGS sample. These results are given in Table B-1. As can be seen from the Table, the volumes of transferred gas were scattered from about $2 \mathrm{~mL}$ to 7 ess than $4 \mathrm{~mL}$.

\begin{tabular}{|c|c|c|c|}
\hline \multicolumn{4}{|c|}{$\begin{array}{c}\text { TABLE B-1 } \\
\text { LABORATORY SIMULATION TESTS - HELIUM BACKFILLED SAMPLERS }\end{array}$} \\
\hline Test \# & $\begin{array}{l}\text { Total STP Volume } \\
(\mathrm{mL})\end{array}$ & $\begin{array}{l}\text { Hel ium } \\
\text { (\%) }\end{array}$ & $\begin{array}{l}\text { Aging Time } \\
\text { (hrs) }\end{array}$ \\
\hline 1 & 3.44 & 97.97 & 2 \\
\hline 3 & 1.98 & 62.4 & 335 \\
\hline 4 & 2.21 & 76.2 & 145 \\
\hline 5 & 2.11 & 90.9 & 73 \\
\hline 7 & 3.38 & 29.7 & 984 \\
\hline 8 & 1.49 & 91.0 & 21 \\
\hline 10 & 3.52 & 35.7 & 1152 \\
\hline 11 & 3.68 & $92: 7^{*}$ & 482 \\
\hline 12 & 1.95 & $94.6^{*}$ & 1010 \\
\hline \multicolumn{4}{|c|}{$\begin{array}{l}\text { Samplers were enclosed in He backfilled (and sealed) PVC containers. The PVC glue } \\
\text { outgassed organics - these organics are included as part of the helium when calculating } \\
\text { percentage, since they are not due to air in-leakage. The final sampler enclosure } \\
\text { canisters will be made out of stainless steel, so that the outgassing problem will be } \\
\text { eliminated. }\end{array}$} \\
\hline
\end{tabular}

It should be noted in passing that the primary reason for performing the laboratory tests was to verify the retention of helium. The first ten tests were performed on helium backfilled samplers not enclosed in a helium backfilled canister during aging; the helium concentration remained above 90 percent only for about three days. For the last three tests, the samplers were enclosed in helium backfilled containers during the aging period, and the helium (plus organics) concentration remained above 90 percent after 42 days.

In Table B-2, the apparent volume of air contamination introduced from the 


\begin{tabular}{|c|c|c|c|c|c|c|c|}
\hline \multicolumn{8}{|c|}{$\begin{array}{l}\text { TABLE B-2: RGS TRAPPED AIR VOLUME DETERMINATION } \\
\text { (Assumes no Oxygen Reactivity with Waste) }\end{array}$} \\
\hline Tank & Riser & Segment & $\begin{array}{l}\text { oxygen } \\
\text { (umole) }\end{array}$ & $\begin{array}{c}\text { Calcul. Air } \\
\text { a STP (mL) }\end{array}$ & $\begin{array}{l}\text { Argon * } \\
\text { ( } \mu \text { mole) }\end{array}$ & $\begin{array}{l}\text { Argon Vol. } \\
\text { a STP (mL) }\end{array}$ & $\begin{array}{l}\text { Air+Argon } \\
\text { a STP (mL) }\end{array}$ \\
\hline \multirow[t]{6}{*}{ AN-101 } & $24 A$ & 8 & 17.8 & 1.90 & 13.3 & 0.30 & 2.20 \\
\hline & & 17 & 30.2 & 3.23 & 7.7 & 0.17 & 3.40 \\
\hline & & 19 & 23.1 & 2.47 & 7.8 & 0.17 & 2.64 \\
\hline & & 21 & 18.7 & 2.00 & 7.7 & 0.17 & 2.17 \\
\hline & $24 B$ & 18 & 31.7 & 3.39 & 21.8 & 0.49 & $3.88^{\circ}$ \\
\hline & & 22 & 13.8 & 1.48 & 13.8 & 0.31 & 1.79 \\
\hline \multirow[t]{6}{*}{$A-101$} & 15 & 5 & 12.1 & 1.29 & 5.0 & 0.11 & 1.40 \\
\hline & & 8 & 12.7 & 1.36 & 3.0 & 0.07 & 1.43 \\
\hline & & 12 & 17.0 & 1.82 & 60.7 & 1.36 & 3.18 \\
\hline & 24 & 9 & 3.3 & 0.35 & 90.0 - & 2.02 & 2.37 \\
\hline & & 16 & 8.0 & 0.86 & 93.8 & 2.10 & 2.96 \\
\hline & & 19 & 25.1 & 2.69 & 93.5 & 2.09 & 4.79 \\
\hline \multirow[t]{7}{*}{ AN-105 } & $12 \mathrm{~A}$ & 15 & 27.6 & 2.95 & 2.0 & 0.04 & 2.99 \\
\hline & & 17 & 23.4 & 2.50 & 2.4 & 0.05 & 2.55 \\
\hline & & 19 & 24.7 & 2.64 & 2.6 & 0.06 & 2.70 \\
\hline & & 21 & 4.7 & 0.50 & 118.1 & 2.65 & 3.15 \\
\hline & $7 \mathrm{~B}$ & 4 & 23.0 & 2.46 & 33.3 & 0.75 & 3.21 \\
\hline & & 16 & 19.7 & 2.11 & 27.3 & 0.61 & 2.72 \\
\hline & & 18 & 16.4 & 1.75 & 14.2 & 0.32 & 2.07 \\
\hline \multirow[t]{6}{*}{$A N-104$} & $10 \mathrm{~A}$ & 3 & 32.0 & 3.42 & 2.1 & 0.05 & 3.47 \\
\hline & & 13 & 23.3 & 2.49 & 2.6 & 0.06 & 2.55 \\
\hline & & 15 & 17.6 & 1.88 & 2.7 & 0.06 & 1.94 \\
\hline & & 17 & 88.5 & 9.47 & 6.1 & 0.14 & 9.61 \\
\hline & & 21. & 14.7 & 1.57 & 43.7 & 0.98 & 2.55 \\
\hline & $12 \mathrm{~A}$ & 18 & 24.2 & 2.59 & 6.4 & 0.14 & 2.73 \\
\hline \multirow[t]{5}{*}{ AN- 103} & $12 \mathrm{~A}$ & 2 & 21.0 & 2.25 & 1.9 & 0.04 & 2.29 \\
\hline & & 5 & 20.9 & 2.24 & 1.4 & 0.03 & 2.27 \\
\hline & & 14 & 15.2 & 1.63 & 2.3 & 0.05 & 1.68 \\
\hline & $21 \mathrm{~A}$ & 10 & 29.1 & 3.11 & 5.6 & 0.13 & 3.24 \\
\hline & & 16 & 2.8 & 0.30 & 17.3 & 0.39 & 0.69 \\
\hline
\end{tabular}

* (Shekarriz, 1996) 
interface volume during RGS sampling in the first five tanks is calculated; these calculations assume that a minimal amount of oxygen was lost to reaction with the waste. With the exception of four "flyers" (out of the thirty segments evaluated in Table B-2), the calculated volumes of air contamination ranged from $1.3 \mathrm{~mL}$ to $4 \mathrm{~mL}$. Also shown in Table B-2 are the argon volumes found in these samples, and in the last column of the Table, the air and argon volumes are added together. Three of the four "flyers" are "fixed" when argon is included. Averages and standard deviations were calculated for the volume data in Tables B-1 and B-2, and are presented in Table B-3.

\begin{tabular}{|c|c|c|c||}
\hline \multicolumn{4}{|c|}{ TABLE B-3 } \\
\hline Statistics for RGS "Contamination" Volumes at STP \\
\hline Statistic & Lab Test - Helium & $\begin{array}{c}\text { Five Tank } \\
\text { Cal. Air } \\
(\mathrm{mL})\end{array}$ & $\begin{array}{c}\text { Five Tank } \\
\text { Air+Argon } \\
(\mathrm{mL})\end{array}$ \\
\hline AVERAGE & 2.64 & 2.04 & 2.59 \\
\hline $\begin{array}{c}\text { STANDARD } \\
\text { DEVIATION }\end{array}$ & 0.80 & 0.84 & 0.81 \\
\hline
\end{tabular}

Note that the averages and standard deviations are similar between the $1 \mathrm{ab}$ test helium volumes and the tank RGS air volumes; when tank RGS argon volumes are added to the air volumes, the agreement with the lab test data improves significantly. This suggests that some argon purge gas was often trapped with the RGS interface gases, and included with the sample gases.

Now that the first five RGS tanks have been sampled and the preliminary report issued (Shekarriz, 1996) evaluating that data, RGS testing has resumed (starting in tank U-103). Helium backfilled samplers (enclosed in stainless steel canisters until just before sampling) were used in U-103, and will continue to be used in subsequent RGS tanks.

Although it is premature to report the complete results obtained from these new RGS tanks, an evaluation of the effectiveness of the helium backfill samplers is made here for the first four RGS segments obtained in U-103. The quantities of helium and oxygen identified in these samples are given in Table B-4.

As can be seen from Table B-4, the helium backfill technique was very effective in replacing interface trapped air with helium. The oxygen content of these samplers was greatly reduced, and the resulting calculated air volume (assuming no oxygen reaction with the waste) may be due in part to test system leakage. For example, at the RGSS maximum allowable leak-rate currently set at $0.003 \mu \mathrm{moles} / \mathrm{s}$, as much as $0.48 \mathrm{~mL}$ of air could leak into the system over a typical two hour test. 


\begin{tabular}{|c|c|c|c|c|c||}
\hline \hline \multicolumn{7}{|c||}{$\begin{array}{c}\text { TABLE B-4 } \\
\text { Effectiveness of Hel ium Backfi11 Technique } \\
\text { U-103, Riser 7 }\end{array}$} & $\begin{array}{c}\text { Total } \\
\text { Segment } \\
\#\end{array}$ & $\begin{array}{c}\text { Hel ium } \\
\text { OSTP (mL) }\end{array}$ & $\begin{array}{c}\text { Oxygen } \\
\text { OSTP (mL) }\end{array}$ & $\begin{array}{c}\text { Calcul. } \\
\text { Air } \\
\text { OSTP (mL) }\end{array}$ & $\begin{array}{c}\text { Argon } \\
\text { OSTP (mL) }\end{array}$ & $\begin{array}{c}\text { Contamination Gas } \\
\text { OSTP (mL) }\end{array}$ \\
\hline \hline 2 & 3.14 & 0.10 & 0.48 & 0.05 & 3.67 \\
\hline \hline 5 & 2.18 & 0.06 & 0.29 & 0.01 & 2.48 \\
\hline 7 & 3.32 & 0.04 & 0.19 & 0.01 & 3.52 \\
\hline 8 & 3.96 & 0.12 & 0.55 & 0.03 & 4.54 \\
\hline
\end{tabular}

Again, the total volume of "contamination" gases ranges from 2.5 to $4.5 \mathrm{~mL}$; although slightly larger on the average $(3.53 \mathrm{~mL})$ these volumes are similar to those obtained during the previously described laboratory testing and the prehelium sampler air contamination noted for the first five RGS tanks. 


\begin{tabular}{|c|c|c|c|c|c|}
\hline \multicolumn{6}{|c|}{ DISTRIBUTION SHEET } \\
\hline \multirow{2}{*}{$\begin{array}{l}\text { To } \\
\text { Distribution }\end{array}$} & \multirow{2}{*}{\multicolumn{3}{|c|}{$\begin{array}{l}\text { From } \\
\text { Equipment Development Laboratory }\end{array}$}} & \multicolumn{2}{|l|}{ Page 1 of 1} \\
\hline & & & & \multicolumn{2}{|c|}{$\begin{array}{l}\text { Date } \\
\text { March 12, } 1997\end{array}$} \\
\hline \multirow{2}{*}{\multicolumn{4}{|c|}{$\begin{array}{l}\text { Project Title/Work Order } \\
\text { Retained Gas Sampler Interface Volume }\end{array}$}} & \multicolumn{2}{|c|}{ EDT No. 606753} \\
\hline & & & & \multicolumn{2}{|c|}{ ECN No. N/A } \\
\hline Name & MSIN & $\begin{array}{c}\text { Text } \\
\text { With All } \\
\text { Attach. }\end{array}$ & Text Only & $\begin{array}{l}\text { Attach./ } \\
\text { Appendix } \\
\text { Only }\end{array}$ & $\begin{array}{l}\text { EDT/EC } \\
\text { N Only }\end{array}$ \\
\hline J. M. Bates & K7-15 & $\mathrm{x}$ & & & \\
\hline R. E. Bauer & S7-14 & $\mathrm{X}$ & & & \\
\hline N. S. Cannon (5) & L6-38 & $\mathrm{X}$ & & & \\
\hline A. B. Cockrell & S7-12 & $\mathrm{X}$ & & & \\
\hline P. R. Deichelbohrer & S7-12 & $\mathbf{X}$ & & & \\
\hline B. E. Hey & T6-09 & $\mathrm{X}$ & & & \\
\hline J. R. Jewett & T6-09 & $\mathrm{x}$ & & & \\
\hline G. D. Johnson & S7-15 & $\mathrm{X}$ & & & \\
\hline C. G. Linschooten & $\$ 7-12$ & $\mathrm{X}$ & & & \\
\hline L. A. Mahoney & K7-15 & $\mathrm{X}$ & & & \\
\hline A. P. Mousel & S7-12 & $\mathrm{X}$ & & & \\
\hline K. Napora & L6-35 & $\mathrm{X}$ & & & \\
\hline L. R. Pederson & K2-44 & $\mathrm{X}$ & & & \\
\hline J. C. Person & T6-09 & $\mathrm{x}$ & & & \\
\hline D. R. Rector & K7-15 & $\mathrm{x}$ & & & \\
\hline J. S. Schofield & S7-12 & $\mathrm{X}$ & & & \\
\hline A. Shekarriz & K7-15 & $\mathrm{X}$ & & & \\
\hline C. W. Stewart & K7-15 & $\mathrm{x}$ & & & \\
\hline J. R. Thielges & L6-38 & $\mathrm{X}$ & & & \\
\hline Central Files $(3)+$ Orig. & A3-88 & $x$ & & & \\
\hline
\end{tabular}

